CASE REPORT

\title{
Mucocele of the Sphenoid Sinus
}

\author{
Karen B. Djambazov' ${ }^{1}$, Borislav D. Kitov², Christo B. Zhelyazkov², Atanas N. Davarski², \\ Alexandrina R. Topalova ${ }^{1}$ \\ ${ }^{1}$ Department of Ear, Nose and Throat Diseases, Faculty of Medicine, Medical University of Plovdiv, Plovdiv, Bulgaria \\ 2 Department of Neurosurgery, Faculty of Medicine, Medical University of Plovdiv, Plovdiv, Bulgaria
}

\section{Correspondence:}

Borislav D. Kitov, Deparment of

Neurosurgery, Faculty of Medicine

Medical University, Plovdiv

15A Vassil Aprilov Blvd.,

4002 Plovdiv, Bulgaria

E-mail: borislavkitov@yahoo.com

Tel: +359898493442

Received: 02 March 2017

Accepted: 31 March 2017

Published Online: 19 May 2017

Published: 22 Dec 2017

Key words: mucocele, sphenoid sinus, transnasal endoscopic sphenoidectomy

Citation: Djambazov KB, Kitov $B D$, Zhelyazkov C, Davarski A Topalova A. Mucocele of the sphenoid sinus.

Folia Medica 2017;59(4):481-5. doi: 10.1515/fomed-2017-0049
Mucocele of the paranasal sinuses is a rare disease with slow evolution. It is a benign, encapsulated and destructive formation filled with mucous fluid and tapistrated with respiratory epithelium. Of all the paranasal sinuses, the sphenoid sinus is affected in only $1-7 \%$ of the cases.

We present two cases of mucocele of the sphenoid sinus involving the posterior ethmoidal cells. We consider here their clinical presentation, use of neuroimaging in the diagnosis, surgical care and postoperative results.

Both patients presented with a history of persistent headache and in addition, one of them had a paresis of the right oculomotor and abducens nerves. A transnasal endoscopic sphenoidectomy was performed in both patients, in one - with an evacuation of the mucocele and marsupialization, and in the other - with a balloon dilatation of the natural foramen of the sinus. Postoperatively, a complete reversal of the symptoms was observed in both patients.

Mucocele of the paranasal sinuses should be considered as a diagnosis in cases of persistent headache with a primarily retrobulbar location and eye symptoms. Computed tomography and magnetic resonance imaging can be used to successfully diagnose the disease. The transnasal endoscopic sphenoidectomy is the therapeutic method of choice which allows evacuation of the mucocele, while the marsupialization allows good drainage and prevents recurrence.

\section{INTRODUCTION}

Mucocele of the paranasal sinuses (MPS) is a benign, encapsulated and destructive formation filled with mucous fluid and tapistrated with respiratory epithelium. ${ }^{1,2}$ The sphenoid sinus is the least often affected $-1-2 \%$ and in single series - up to $7 \% .^{1,3-5}$ The first case of mucocele of the sphenoid sinus (MSS) was reported in 1872 by Rouge and described later by Berg in 1889.6 Headache is the most common clinical presentation of MSS, while the possible neurological deficit is determined by the anatomy of the adjacent structures - II-VI cranial nerves, cavernous sinus, internal carotid artery and pituitary gland. ${ }^{6}$ The specific presentation of the neurological deficit depends on the direction of spread of the mucocele.

We present two cases of mucocele of the sphenoid sinus and posterior ethmoidal cells of different sizes associated only with a pronounced headache in one of the cases and headache and ophthalmic symptoms in the other, and we analyze the clinical presentation depending on the location of the lesions, possibilities for neuroimaging diagnosis and treatment.

\section{CASE HISTORY}

Case 1. A 78-year-old woman presented with a history of gradually increasing headache, mostly retro-orbital, and dizziness over the past year. The vision in the right eye decreased slightly. Ten days before admission to the clinic, double vision appeared and the eyelid of the right eye closed. There was no evidence in the patient's history of inflammation of the paranasal sinuses or previous craniocerebral trauma.

At admission of the patient to the Department of Neurosurgery in St George University Hospital, Plovdiv, the local status established ptosis of the right eyelid, and the neurologic status - paresis of the right oculomotor and abducens nerves. The 
laboratory blood tests (leucocytes, erythrocyte sedimentation rate and C-reactive protein) did not show any evidence of an inflammatory process. The magnetic resonance imaging (MRI) visualized a large cystic formation in the region of the sphenoid sinus with sizes in the three planes of around 25/46/35 $\mathrm{mm}$. In the T1 weighted image, the signal was of moderate to high intensity, and in the T2 weighted image, it ranged from high to moderate intensity which was a result of the increased protein concentration and dehydration indicative of a long-term process (Fig. 1. A, B). The injected contrast material collected minimally in the periphery (Fig. 1A). There was destruction of the wall of the sphenoid sinus, involvement of the posterior ethmoidal cells and parasellar compression of the right cavernous sinus (Fig. $1 \mathrm{~A}-\mathrm{C}$ ).

Case 2. A 30-year-old woman complained of a headache over the past 2-3 months which did not respond to analgetics and a feeling of heaviness in the facial region, more pronounced on the right.

No neurological deficit was found at admission of the patient to the Department of Ear, Nose and Throat Diseases in St George University Hospital, Plovdiv. No concurrent diseases or deviations from the normal status for her age were found. There was no evidence in the history of the patient of inflammation of the paranasal sinuses or previous craniocerebral trauma. From the laboratory tests, only the erythrocyte sedimentation rate was slightly elevated $(24 \mathrm{~mm} / \mathrm{h})$. The computed tomography found a soft tissue formation involving the sphenoid sinus and the right ethmoidal cells, with density of 58 to $149 \mathrm{HU}$ and calcifications. The MRI confirmed the CT findings and the signals in $T 1$ and T2 weighted images were similar in strength to those in Case 1.

The diagnosis in both cases was found to be MSS and an endoscopic optically supported sphenoidectomy was performed. In the first patient, evacuation and marsupialization of the mucocele was performed (Fig. 2), and in the second patient - a balloon dilatation of the natural foramen of the sinus and drainage of the mucocele.

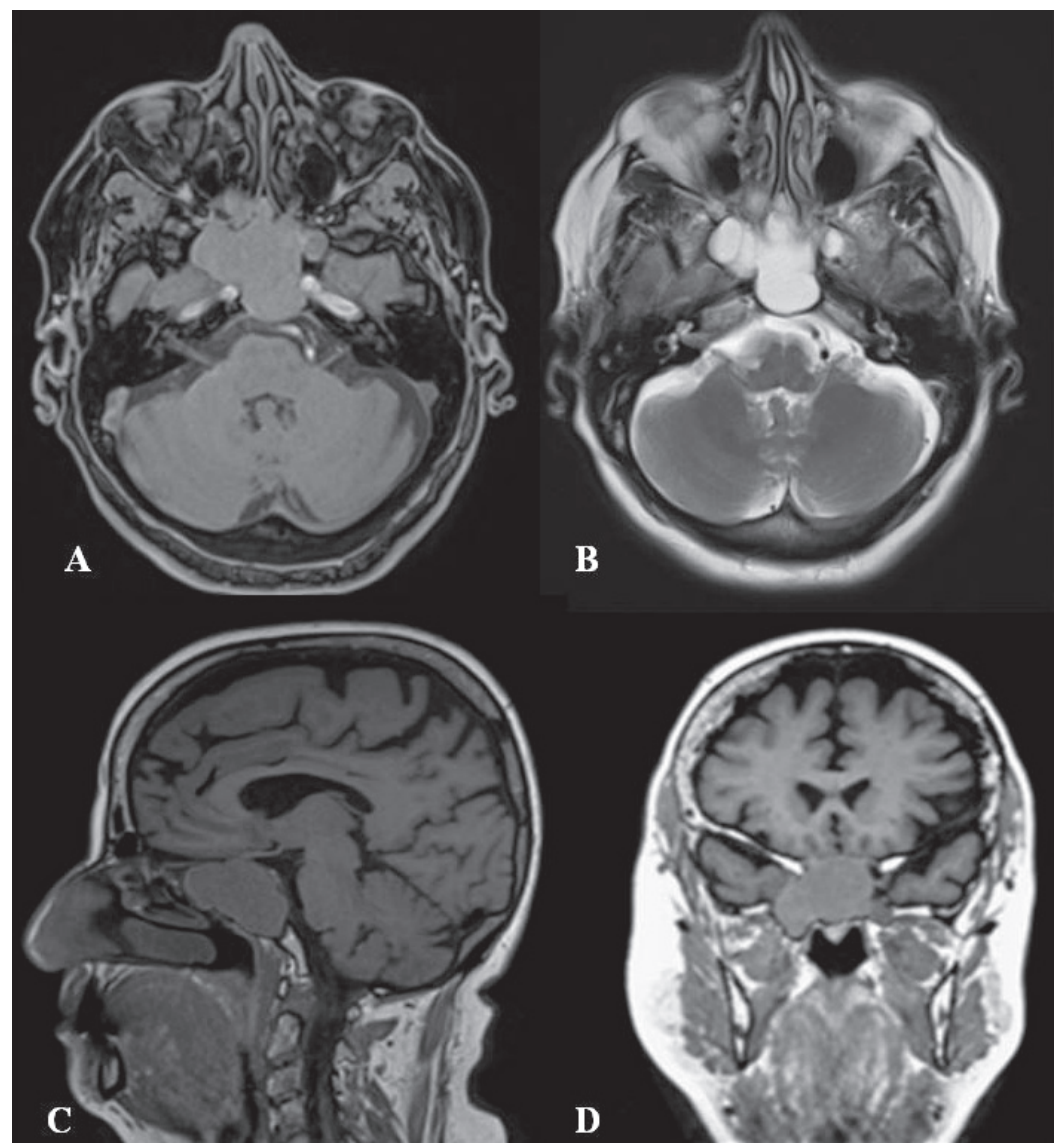

Figure 1. MRI: A large cystic lesion fills the sphenoid sinus and extends beyond its border (more on the right), and in such a way compresses the right cavernous sinus. A. T1 weighted image with contrast: the lesion has a moderate to high intensity and the contrast material collects minimally in the periphery; B. T2 weighted image without contrast - high to moderate intensity of the signal; C. and D. sagittal and coronal view. 


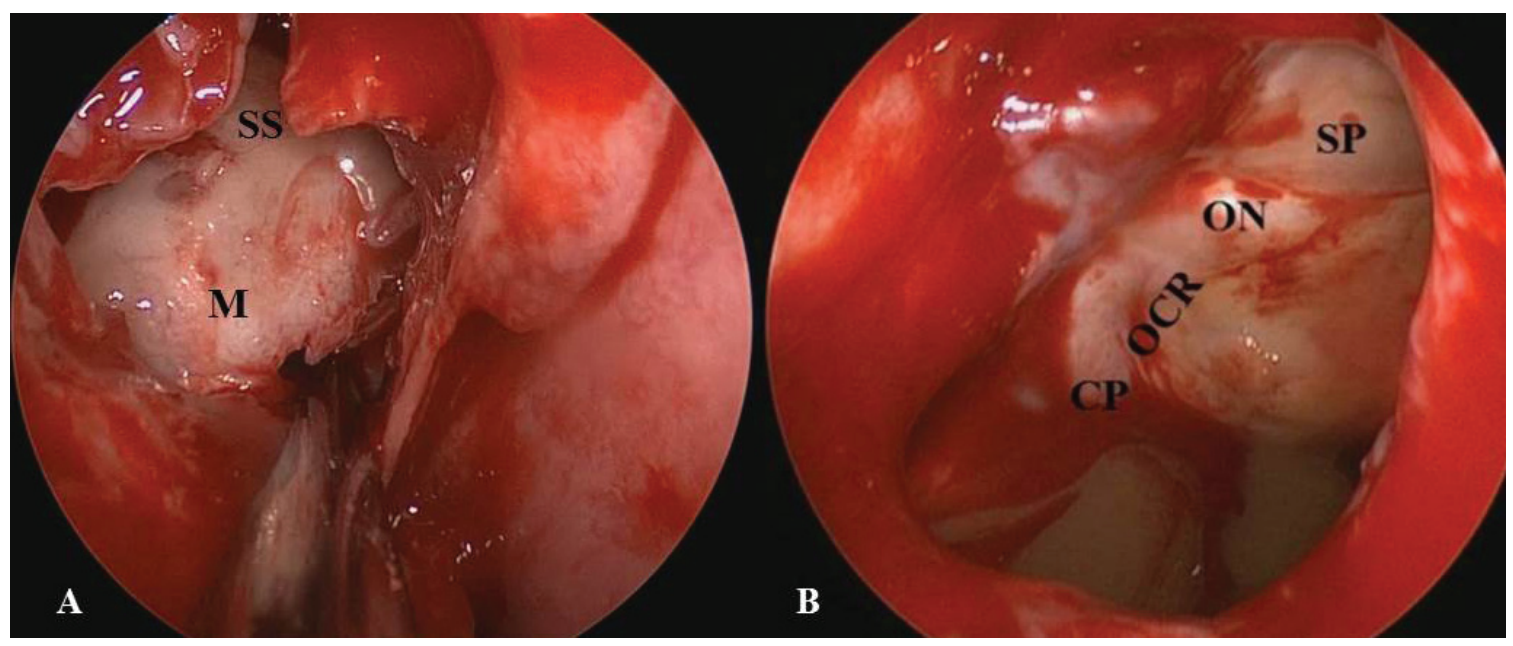

Figure 2. A. Endoscopic presentation of the mucocele (M), affecting the cavity of the sphenoid sinus (SS); B. Status after evacuation and marsupialization of the mucocele. Visualized are planum sphenoidale (SP), anatomic projections of the carotid protuberance $(\mathrm{CP})$, optic nerve $(\mathrm{ON})$ and opticocarotid recess $(\mathrm{OCR})$.

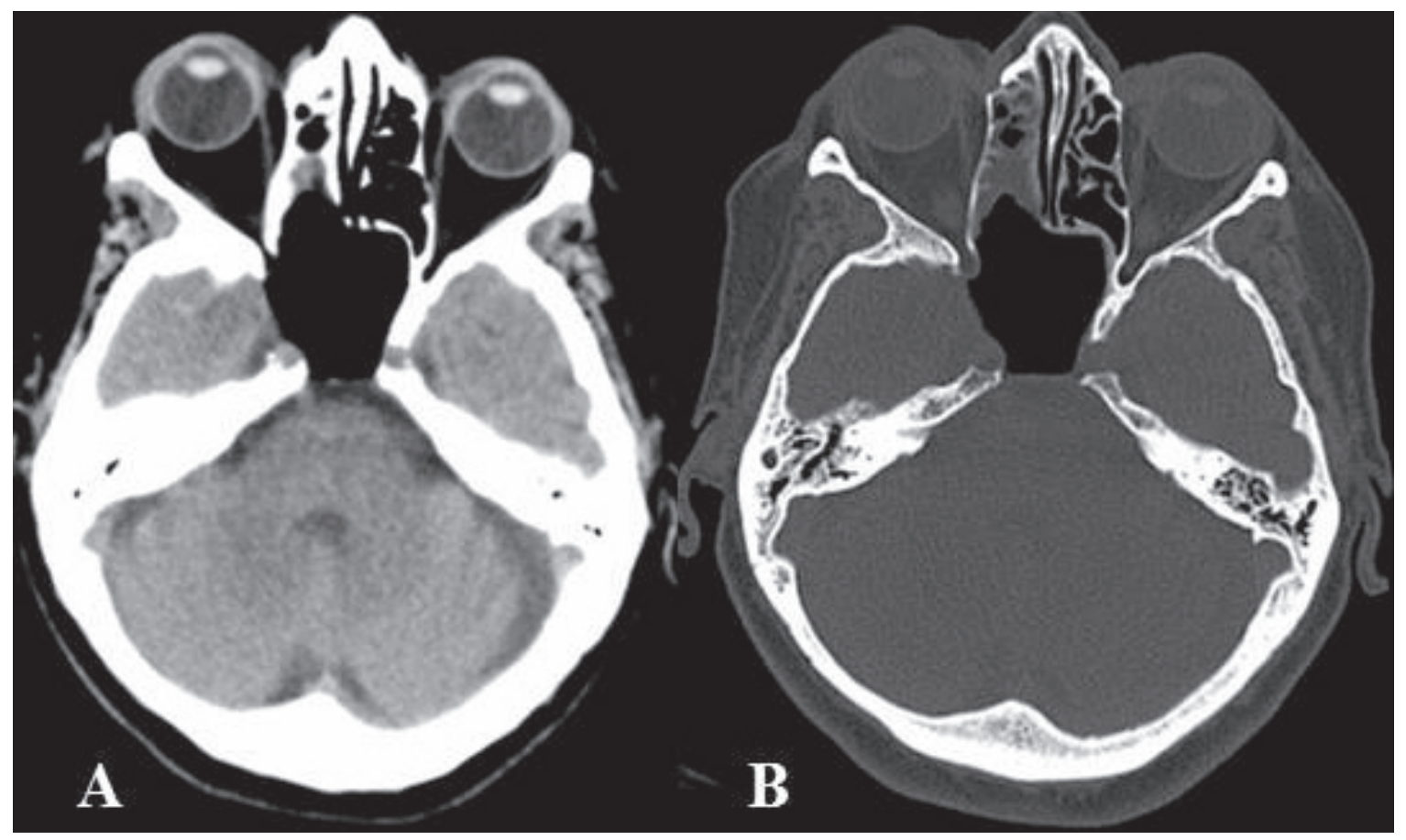

Figure 3. Control CT of the Case 1. A. Native; B. Bone view. Expanded sphenoid sinus with destroyed bone septs..

The postoperative period was uneventful (no bleeding from the nose or liquorrhea). In both patients, the headache showed a tendency to decrease. The pareses of the oculomotor and abducens nerves in the first patient resolved completely and the vision in the right eye improved. The histological result showed bone fragments, polypoid changes and pseudoneoplastic respiratory epithelium. The postoperative CTS showed an evacuation of the mucocele and no compression of the surrounding structures (Fig. 3).

\section{DISCUSSION}

The etiology of MSS is not fully understood. The proposed theories for its development include cystic dilatation of glandular structures and cystic dilata- 
tion of embryonic epithelial remains. ${ }^{7}$ Previous craniocerebral traumas and inflammations (polypoid sinusitis) are considered to be the most likely reasons for the occurrence of mucocele. ${ }^{8}$ Similar to the case of T. Adouly et al., a single risk factor for the occurrence of the disease was not found in our patient. ${ }^{1}$

The clinical presentation of MSS is not specific and quite varied, as the time from the debut of the disease to the diagnosis ranges from 3 days to 38 years, with an average of 4 years. ${ }^{3}$ Headache is the most common clinical symptom of MSS - it is observed in $70-80 \%$ of the cases, its location being typically retro-orbital. ${ }^{9-11}$ The headache is due both to the mechanical pressure on the dura mater covering planum sphenoidale or floor of the anterior cranial fossa, as well as cytokines present in the mucocele contents (TNF alpha, IL-6, IL-1, and PGE2), which modulate the trigeminal sensitivity of pain threshold. . $^{910}$ Ocular disturbances are the second most common group of symptoms, which require emergency surgery. ${ }^{1}$ The optic nerve is the most commonly affected cranial nerve, which leads to a decrease in visual acuity. Disturbances in the cranial nerves that control eye movement occur in $30-50 \%$ of cases and the oculomotor nerve is affected significantly more often $-70 \%$ of cases. ${ }^{10}$ Both of the cases we present confirm this characterization of the clinical presentation.

The treatment of MSS is surgical. The goal of treatment is to remove the mucocele and to create good opportunity for drainage to the sphenoethmoidal recessus. ${ }^{3}$ For this purpose, an endoscopic transnasal access is currently used, through which the sphenoid sinus is penetrated, enabling adequate drainage by opening the anterior wall, marsupialization of the mucocele and/or balloon dilatation of the natural foramen. This significantly decreases the possibility of recurrence of the disease. ${ }^{4}$ This endoscopic surgical access is not very invasive and has a low risk of opening dura mater and penetration of infection. ${ }^{3,6}$

\section{CONCLUSION}

Mucocele of the sphenoid sinus is a rare disease, which may be present in cases of persistent retro- bulbar headache and disturbances in vision and the cranial nerves that control eye movement. In these cases, a computed tomography or magnetic resonance imaging is needed not only for the diagnosis, but also for differential diagnosis with other lesions in this area of the skull base. The transnasal endoscopic sphenoidectomy with marsupialization of the cyst is the therapeutic method of choice.

\section{REFERENCES}

1. Adouly T, Adnane C, Loufad FZ, et al. A rare cause of diminished vision: large spheno-ethmoidal mucocele. Otorhinolaryngol Head Neck Surg 2016;1(2):51-2.

2. Dzhambazov K, Traykova N, Yovchev I. Endonasal surgery in mucopyocele of the paranasal sinuses. Folia Med (Plovdiv) 2001;18(4):19-22.

3. Arkha Y, Benazzou S, El Ouahabi A, et al. Mucocèle géante sphénoïdale: A propos d'un cas. Fr ORL 2007;92:312-4.

4. Bahgat $\mathrm{M}$, Bahgat $\mathrm{Y}$, Bahgat A. Sphenoid sinus mucocele. BMJ Case Rep 2012;2012. doi: 10.1136/ bcr-2012-007130.

5. Martel-Martín M, Gras-Cabrerizo JR, BotheGonzález C, et al. [Clinical analysis and surgical results of 58 paranasal sinus mucoceles]. Acta Otorrinolaringol Esp 2015;66(2):92-7 [Spanish].

6. Stankiewicz JA. Sphenoid sinus mucocele. Arch Otolaryngol Head Neck Surg 1989;115:735-40.

7. Friedman A, Batra PS, Fakhri S, et al. Isolated sphenoid sinus disease: etiology and management. Otolaryngol Head Neck Surg 2005;133:544-50.

8. Malard O, Gayet-Delacroix M, Jegoux F, et al. Spontaneous sphenoid sinus mucocele revealed by meningitis and brain abscess in a 12-year-old child. AJNR Am J Neuroradiol 2004;25:873-5.

9. Giovannetti F, Filiaci F, Ramieri V, et al. Isolated sphenoid sinus mucocele: etiology and management. J Craniofac Surg 2008;19:1381-4.

10. Lee JC, Park SK, Jang DK, et al. Isolated sphenoid sinus mucocele presenting as third nerve palsy. J Korean Neurosurg Soc 2010;48:360-2.

11. Kariya S, Okano M, Hattori $\mathrm{H}$, et al. Expression of IL-12 and T helper cell 1 cytokines in the fluid of paranasal sinus mucoceles. Am J Otolaryngol 2007;28:83-6. 


\section{Мукоцеле сфеноидального синуса}

\section{Карен В. Джамбазов ${ }^{1}$, Борислав Д. Китов ${ }^{2}$, Христо Б. Желязков ${ }^{2}$, Атанас Н. Даварски², Александрина Р. Топалова ${ }^{1}$}

${ }^{1}$ Кафедра оториноларингологии, Факультет медицины, Медицинский университет - Пловдив, Пловдив, Болгария

2 Кафедра нейрохирургии, Факультет медицины, Медицинский университет - Пловдив, Пловдив, Болгария

Адрес для корреспонденции: Борислав Д. Китов, Кафедра нейрохирургии, Факультет медицины, Медицинский университет - Пловдив, бул. „Васил Априлов" 15 А, Пловдив 4002, Болгария

E-mail: borislavkitov@yahoo.com Тел: +359898493442

Дата получения: 02 марта 2017 Дата приемки: 31 марта 2017 Дата онлайн публикации: 19 мая 2017

Дата публикации: 22 декабря 2017

Ключевые слова: мукоцеле, сфеноидальный синус, трансназальная эндоскопическая спеноидэктомия

\section{Образец цитирования:}

Djambazov KB, Kitov BD,

Zhelyazkov C, Davarski A, Topalova A. Mucocele of the sphenoid sinus.

Folia Medica 2017;59(4):481-5. doi: 10.1515/fomed-2017-0049
Мукоцеле параназальных синусов является редким заболеванием с медленной эволюцией. Оно представляет собой доброкачественное, капсулярное и деструктивное образование, которое наполнено слизистой жидкостью и выстлано респираторным эпителием. Из всех параназальных синусов, поражение сфеноидального синуса встречается лишь в рамках 1 - 7\% из случаев.

Нами представлены два случая мукоцеле сфеноидального синуса задних этмоидальных клеток. Были обсуждены клиническое представление, возможности диагностики методом нейровизуализации, хирургическая помощь и послеоперативные результаты

Оба пациента жаловались на постоянную головную боль, а у одного из них был парез глазодвигательного и отводящего нервов правого глаза. Была проведена трансназальная эндоскопическая спеноидэктомия обоим пациентам, одному - с удалением мукоцеле и марсупиализацией, а другому - с применением балонной синусопластики для расширения естественного отверстия синуса. В послеоперационный период установлено полное исчезновение симптомов у обоих пациентов.

Мукоцеле параназальных синусов необходимо иметь ввиду в качестве диагноза при наличии персистирующей боли с первичной ретро-тубулярной локализацией и проблем с глазами. Компьютерная томография и ядерная магнитно-резонансная томография позволяют диагностировать заболевание. Трансназальная эндоскопическая спеноидэктомия является предпочитаемым терапевтическим методом, позволяющим удаление мукоцеле, а марсупиализация обеспечивает хороший дренаж и предотвращает дальнейшие рецидивы. 